\title{
TOLERÂNCIA DE SEMENTES DE SOJA À DESSECAÇÃO ${ }^{1}$
}

\author{
Desiccation tolerance of soybean seeds
}

\author{
Adriano Delly Veiga ${ }^{2}$, Sttela Dellyzete Veiga Franco da Rosa ${ }^{3}$, Paulo de Albuquerque Silva ${ }^{4}$, \\ João Almir de Oliveira ${ }^{5}$, Patrícia de Oliveira Alvim² ${ }^{2}$ Kênia Almeida Diniz ${ }^{4}$
}

\begin{abstract}
RESUMO
A colheita antecipada de sementes, após a maturidade fisiológica, permite a obtenção da melhor qualidade fisiológica e sanitária, rotação de culturas e otimização das estruturas de processamento. Sementes não toleram a secagem durante todos estádios e adquirem tolerância em estádios específicos. Durante a maturação, esta aquisição da tolerância à dessecação pode coincidir com a maturidade fisiológica e, em sementes de soja, ocorre no estádio R7, com umidade ao redor de $45 \%$ a 50\%. Assim, a presente pesquisa teve como objetivo avaliar a tolerância à dessecação de sementes de soja. As sementes foram colhidas em três estádios fenológicos, R6, $\mathrm{R} 6 / \mathrm{R} 7$ e R7 e foram submetidas à secagem artificial a $35^{\circ} \mathrm{C}$ até $20 \%$ de teor de água e a $42^{\circ} \mathrm{C}$ até $13 \%$. Uma quarta colheita foi realizada com sementes secadas no campo, sendo estas utilizadas como testemunha. A qualidade das sementes foi avaliada pelos testes de germinação, de condutividade elétrica, de frio, de peso seco de plântulas e eletroforese de proteínas lea. O delineamento experimental foi inteiramente casualizado em esquema fatorial com quatro repetições. A testemunha foi comparada individualmente com cada tratamento. Com os resultados, concluiu-se que a germinabilidade e a tolerância à dessecação de sementes de soja aumentam com a perda natural de água no campo; sementes colhidas no estádio R7 apresentam maior qualidade fisiológica, padrão diferenciado de proteínas lea e maior tolerância à dessecação do que nos estádios R6 e R6/R7; secagem de sementes colhidas próximo à maturidade induz a síntese de lea proteínas; e sementes colhidas no estádio R7 apresentam qualidade fisiológica e padrão de proteína lea similares aos de sementes secadas no campo até $14 \%$ de teor de água.
\end{abstract}

Termos para indexação: Glycine max, maturação, secagem, lea proteínas.

\begin{abstract}
The anticipated harvest of seeds after physiological maturity allows the obtaining of the better quality physiological, crop rotation and optimization of the processing structures. Seeds do not tolerate dissection over all the stages and acquire tolerance in particular stages During maturation, this acquisition of dissection tolerance may coincide with physiological maturity and in soybean seeds, it take place at R7 stage with moisture close from $45 \%$ to $50 \%$. So, the present research was intended to evaluate dissection tolerance of soybean seeds. The seeds were harvested at three phenologic stages, R6, R6/R7 and R7 and were submitted to artificial drying at $35^{\circ} \mathrm{C}$ to $20 \%$ of water content and at $42^{\circ} \mathrm{C}$ to $13 \%$. A fourth harvest was accomplished with field dried seeds, these being utilized as a control. The quality of seeds was evaluated by tests of germination, electric conductivity and of cold, of dry weight of seedlings and lea protein electrophoresis. The experimental design was completely randomized in factorial scheme with four replicates. The control was compared singly with each treatment. From the results, it follows that both germinability and dissection tolerance of soybean seeds increase with the natural water loss in the field; seeds harvest at R7stage show increased physiologic quality, distinct pattern of lea proteins and greater dissection tolerance than at R6 and R6/R7stages; seeds drying harvested close to maturity induces the synthesis of lea proteins; and seeds harvested at R7 stage present physiological quality and lea protein pattern similar to the ones of filed dried seeds up to $14 \%$ of water content.
\end{abstract}

Index terms: Glycine max, maturation, drying, lea proteins.

(Recebido em 4 de outubro de 2005 e aprovado 20 de março de 2006)

\section{INTRODUÇÃO}

Na produção de sementes, a antecipação da colheita permite a obtenção de sementes de melhor qualidade fisiológica e sanitária, por evitar danos que possam ocorrer no campo devido às condições climáticas adversas, como chuvas na pré-colheita, bem como ataques de pragas e de microrganismos. Além disso, a colheita antecipada permite um melhor planejamento de rotação de culturas e a otimização das estruturas de recepção, secagem e beneficiamento de sementes.

A semente de soja apresenta maturidade fisiológica caracterizada pelo máximo acúmulo de matéria seca, com aproximadamente $45 \%$ a $50 \%$ de umidade (ANDREWS, 1966) e isto ocorre geralmente quando as sementes (e também a vagem) tornam-se amarelas ou tenham perdido completamente a cor verde (RITCHIE et al., 1994). No momento da colheita, além do teor de água, o estádio de

Este trabalho foi preliminar aos trabalhos de tese de Paulo de Albuquerque Silva,doutorando em Agronomia/Fitotecnia/UFLA

${ }^{2}$ Aluno de graduação em Agronomia da Universidade Federal de Lavras/UFLA - Cx. P. 3037 - 37200-000 - Lavras, MG - adrveiga@yahoo.com.br ${ }^{3}$ Pesquisador Dr. da Embrapa Café - sttelaveiga@ufla.br.

${ }^{4}$ Aluno de doutorado em Agronomia/Fitotecnia da Universidade Federal de Lavras/UFLA - Cx. P. 3037 - 37200-000 - Lavras, MG - paulo@ufla.br. ${ }_{5}^{5}$ rofessor Dr. do Departamento de Agricultura/DAG da Universidade Federal de Lavras/UFLA - Cx. P. 3037 - $37200-000$ - Lavras, MG jalmir@ufla.br 
maturação também é importante para a sensibilidade das sementes à dessecação e a secagem apresenta-se como uma exigência para a garantia da qualidade da semente.

No desenvolvimento das sementes ortodoxas, a tolerância à dessecação e a capacidade de germinação das sementes não são características expressadas em todos os estádios de desenvolvimento das sementes, mas adquiridas após a histodiferenciação, em que há um aumento na massa fresca e deposição de reserva, e antes da fase de secagem na maturação (BEWLEY \& BLACK, 1994; KERMODE, 1997). A redução do teor de água nessas sementes proporciona uma redução do metabolismo e um estado de quiescência do embrião. As sementes no estado de quiescência resistem às condições adversas do ambiente $\mathrm{e}$, quando expostas às condições adequadas $\mathrm{e}$ na ausência de dormência, têm a capacidade de retomada do metabolismo no processo de germinação (BEWLEY \& BLACK, 1994).

Durante a maturação de sementes, a aquisição da tolerância à dessecação pode coincidir com a maturidade fisiológica. A habilidade para germinarem em seguida à colheita precede o desenvolvimento de habilidade para germinarem após colheita e rápida secagem artificial (ELLIS et al., 1987). A transição de intolerância para tolerância à dessecação tem sido usualmente reportada como uma mudança drástica, ocorrendo em alguns dias e determinada como a tolerância para um nível de secagem (FISCHER et al., 1988; KERMODE \& BEWLEY, 1985; LONG et al., 1981).

O entendimento das mudanças que ocorrem nas sementes, nos diferentes estádios de desenvolvimento, à medida que estas perdem água, é de fundamental importância para o desenvolvimento de metodologias de secagem de sementes colhidas com altos teores de água. É sabido que, com progressiva perda de água no campo após a maturidade fisiológica, as sementes tornam-se mais tolerantes a temperaturas mais elevadas de secagem, indicando que eventos ocorrem juntamente com a redução do teor de água (ROSA, 2000a). Segundo Ellis \& Hong (1996), existem consideráveis evidências de que tolerância à dessecação pode ser induzida em sementes imaturas (estádios intolerantes), ou mesmo em sementes maduras intolerantes, por meio de tratamentos que imitem os eventos que ocorrem durante a dessecação natural de sementes.

A tolerância à dessecação é o resultado da interação de vários mecanismos que atuam em sinergismo e a ausência ou a deficiência de um deles determina o grau de sensibilidade das sementes ao processo de dessecação. Um mecanismo associado à tolerância à dessecação durante o desenvolvimento de sementes é a expressão de proteínas específicas. Nas sementes tolerantes, proteínas hidrolíticas, como as "late embryogeneses accumulated - lea", são tipicamente acumuladas durante as fases finais da embriogenese em resposta à secagem, à baixa temperatura, salinidade ou tratamento exógeno de ABA, e sua expressão cessa rapidamente após embebição (BLACKMAN et al., 1991).

A função dessas proteínas ainda não está bem esclarecida, mas sua estabilidade, propriedades físicas e abundância em organismos que toleram a desidratação sugerem um importante papel em tolerância à dessecação (BLACKMAN et al., 1991). O papel de proteínas em tolerância à dessecação deve-se à sua habilidade para atrair moléculas de água, mantendo o ambiente local enriquecido de água ou de alguma forma até substituindo a água (BEWLEY \& BLACK, 1985).

Diante do exposto, o objetivo desta pesquisa foi avaliar a tolerância à dessecação de sementes de soja colhidas em estádios próximos da maturação fisiológica, baseado na morfologia da planta e submetidas à secagem artificial.

\section{MATERIAL E MÉTODOS}

O trabalho foi conduzido no Laboratório de Análise de Sementes (LAS) e no Pomar do Departamento de Agricultura (DAG) da Universidade Federal de Lavras (UFLA), no município de Lavras, MG. As sementes foram produzidas no período de novembro/2004 a abril/2005, utilizando a cultivar MG/BR 46 (Conquista). Em solo preparado de maneira convencional, as parcelas foram instaladas com espaçamento de $0.45 \mathrm{~m}$ entre linha e 15 plantas por metro linear. Cada parcela teve 20 linhas de 10 metros totalizando $180 \mathrm{~m}^{2}$, sendo as 18 linhas centrais, de cada parcela, consideradas úteis.

A tolerância à dessecação das sementes foi avaliada, utilizando-se sementes em diferentes estádios fenológicos próximos da maturidade fisiológica. Seguindo a escala proposta por Ferh (FERH \& CAVINESS, 1979), foram realizadas três colheitas de plantas em diferentes estádios de desenvolvimento, R6, R7 e R8, com intervalos de sete dias entre colheitas. O critério para seleção foi a cor da vagem e o conteúdo de água das sementes, sendo a primeira colheita feita quando as sementes estavam totalmente verdes e a última colheita foi realizada quando as sementes atingiram um conteúdo de água de $14 \%$ no campo, sendo estas utilizadas como testemunha. As vagens colhidas foram trilhadas manualmente e levadas ao secador estacionário a uma temperatura de $35^{\circ} \mathrm{C}$ até que

Ciênc. agrotec., Lavras, v. 31, n. 3, p. 773-780, maio/jun., 2007 
alcançassem um grau médio de umidade de $20 \%$, quando então, a temperatura foi elevada para $42^{\circ} \mathrm{C}$ até que atingisse em torno de $13 \%$.

As sementes colhidas nos três estádios de maturação, foram submetidas à avaliação da qualidade fisiológica, antes e após a secagem, por meio dos seguintes testes:

Determinação do teor de água: o teor de água das sementes foi determinado utilizando-se o método da estufa a $105^{\circ} \mathrm{C}$ por 24 horas, em duas repetições para cada tratamento, segundo as Regras para Análise de SementesRAS (BRASIL, 1992). Os resultados foram expressos em porcentagem.

Teste de germinação: o teste de germinação foi realizado segundo os critérios estabelecidos pelas RAS (BRASIL, 1992). Foram utilizadas quatro repetições de 50 sementes por tratamento em rolos de papel tipo "Germitest" a uma temperatura de $25^{\circ} \mathrm{C}$. A quantidade de água adicionada foi de 2,5 vezes o peso do papel, visando umedecimento adequado e uniformização do teste. As contagens foram feitas no sétimo dia após a semeadura e os resultados expressos em porcentagem.

Teste de condutividade elétrica: realizado com quatro repetições de 50 sementes por tratamento. As sementes foram pesadas com precisão de duas casas decimais, e em seguida, colocadas em copos plásticos descartáveis com $75 \mathrm{~mL}$ de água destilada. Após 24 horas de embebição sob temperatura de $25^{\circ} \mathrm{C}$, a condutividade elétrica foi determinada com auxílio de um condutivímetro Digimed modelo CD-21, com os resultados expressos em ìS. ${ }^{-1} \mathrm{~cm} \cdot{ }^{-1} \mathrm{~g} \cdot{ }^{-1}$, de acordo com o método descrito por Krzyzanowski et al. (1991).

Teste de frio: foram utilizadas quatro subamostras de 50 sementes distribuídas em caixas plásticas contendo mistura de areia e terra, na proporção de $2: 1$, com umidade ajustada para $70 \%$ da capacidade de retenção. As caixas foram mantidas em câmara fria a $10^{\circ} \mathrm{C}$ por cinco dias e, então, transferidas para câmaras de crescimento a $25^{\circ} \mathrm{C}$ e a contagem de plântulas emersas foi feita no sétimo dia com os resultados expressos em porcentagem (KRZYZANOWSKI et al., 1991).

Peso seco de plântulas ao final do teste de frio: as plântulas foram cortadas na base do caule, desprovidas dos cotilédones, colocadas em sacos de papel e secadas em estufa de circulação forçada, sob temperatura de $60^{\circ} \mathrm{C}$, até atingirem peso constante. $\mathrm{O}$ peso seco médio foi obtido, dividindo-se o peso total por 50 , número de sementes que foram semeadas no teste de frio (KRZYZANOWSKI et al., 1991).
Eletroforese de proteínas lea: Durante o processo de secagem, foram retiradas amostras de sementes para a realização da eletroforese de proteínas lea. De todos os estádios de maturação, foram tomadas amostras de sementes sem secagem, de sementes secadas por duas horas a $35^{\circ} \mathrm{C}$ até $20 \%$ de umidade e, de sementes secadas por duas horas a $35^{\circ} \mathrm{C}$ mais secagem a $42^{\circ} \mathrm{C}$ até $13 \%$ de umidade. Para a eletroforese, foram utilizadas duas repetições de 11 embriões de sementes colhidas em cada estádio. Estes foram moídos em cadinho (sobre gelo), adicionando-se tampão de extração descrito por Alfenas (1998), na proporção de 10 partes de tampão para 1 de amostra. As amostras foram centrifugadas a $16000 x g$ por 30 minutos a $4^{\circ} \mathrm{C}$ e o sobrenadante foi separado e incubado em banho-maria a $85^{\circ} \mathrm{C}$ por 10 minutos. Em seguida repetiuse a centrifugação como descrita anteriormente, recolheuse o sobrenadante, aplicou-se o extrato de Lea proteína e o tampão da amostra na canaleta, em gel de poliacrilamida SDS-PAGE a 12,5\% (gel separador) e $6 \%$ (gel concentrador). Promoveu-se a corrida eletroforética, realizada a $150 \mathrm{~V}$ por 4 horas, descrita por Alfenas (1998). A coloração dos géis foi feita utilizando-se solução de Coomassie Blue 0,05\% por 12 horas e solução de ácido cítrico para descoloração.

$\mathrm{O}$ delineamento experimental utilizado foi o inteiramente casualizado em esquema fatorial de dois (sem secagem e com secagem) x três estádios (R6, R6/R7 e R7), com quatro repetições. Utilizou-se o progama Sisvar (FERREIRA, 2000) para a análise de variância dos resultados dos testes de avaliação da qualidade fisiológica. Foi realizada a análise de regressão para os resultados quantitativos de estádio. A testemunha, a qual não foi parte integrante do fatorial, foi comparada individualmente com cada tratamento, por meio teste de Dunnett.

\section{RESULTADOS E DISCUSSÃO}

Os teores de água em que foram colhidas as sementes nos quatro estádios de maturação foram de $57 \%$ em R6, 55\% na transição para R7, 50\% em R7, e 14\% nas sementes secadas no campo.

$\mathrm{Na}$ análise de variância do fatorial, foram observadas diferenças significativas para a interação secagem x estádio de colheita apenas para o teste de condutividade elétrica (Tabela 1). Por outro lado, na análise dos resultados de germinação e de teste de frio verifica-se que houve efeito significativo de estádios e de secagem, não sendo significativa a sua interação. Para os resultados de peso seco de plântulas apenas a secagem foi significativa. 
Nos resultados do teste de condutividade elétrica (Tabela 2) observam-se valores menores nas sementes não submetidas à secagem, para todos os estádios de maturação. Quando as sementes foram submetidas à secagem, houve uma redução nos valores de condutividade elétrica à medida que os estádios de colheita avançaram, indicando que as sementes colhidas com maior teor de água, estavam menos tolerantes à dessecação. Os valores de condutividade elétrica, em sementes não secadas, variaram de $27,94 \mu$ mhos $\mathrm{cm}^{-1} \mathrm{~g}^{-1} \mathrm{em}$ sementes colhidas com $50 \%$ de umidade a 33,63 $\mu$ mhos $\mathrm{cm}^{-1} \mathrm{~g}^{-1}$ em sementes colhidas com $57 \%$ umidade. Já nas sementes secadas, variaram de 90,48 $\mu$ mhos $\mathrm{cm}^{-1} \mathrm{~g}^{-1}$, nas colhidas com $50 \%$ de umidade, a 216,74 $\mu$ mhos $\mathrm{cm}^{-1} \mathrm{~g}^{-1}$, nas colhidas com $57 \%$ de umidade (Tabela 2). Esse padrão também foi observado por Powell (1986).

Com o avanço do processo de maturação, ocorre o desenvolvimento e a organização estrutural dos sistemas de membranas celulares, o que explica a redução nos valores de condutividade elétrica. Nas sementes colhidas em estádio de maturação mais avançado, os mecanismos de proteção de membranas para tolerar a dessecação estão presentes, podendo, assim, promoverem uma diminuição na lixiviação de solutos após a secagem, indicando uma melhor estruturação das membranas, as quais podem ser favorecidos pela síntese de proteínas lea (SUN \& LEOPOLD, 1993).

A porcentagem de germinação das sementes não submetidas à secagem artificial foi de $85 \%$, superior àquelas secadas, as quais apresentaram germinação de 71\% (Tabela 3). Em relação aos estádios de colheita, verificou-se um maior valor de germinação à medida que houve redução no teor de água, sendo de $90 \%$ nas sementes colhidas com 50\%, mais maduras (Figura1). Ellis et al. (1987) verificaram que a máxima qualidade da semente, seguida de colheita e secagem, foi adquirida quando a maturidade das sementes avançou e o teor de água atingiu de 45-50\%. Pode-se observar que um avanço na maturação das sementes resultou em um aumento na germinação, mostrando que a redução de água das sementes pode induzir uma mudança de desenvolvimento para a germinação (KERMODE et al., 1989).

TABELA 1 - Resumo da análise de variância dos resultados da avaliação de qualidade físiológica das sementes de soja, cultivar MG/BR46, colhidas em diferentes estádios de maturação e submetidas à secagem. UFLA, 2005.

\begin{tabular}{lccccccccc}
\hline $\begin{array}{c}\text { Fontes } \\
\text { de } \\
\text { Variação }\end{array}$ & G.L. & & Condutividade & & \multicolumn{7}{c}{ Quadrados Médios } \\
\cline { 3 - 9 } & Germinação & & Teste de frio & \multicolumn{2}{c}{$\begin{array}{c}\text { Peso seco de } \\
\text { plântula }\end{array}$} \\
\hline Estádios & 2 & 9238,0008 & $* *$ & 1072,1667 & $* *$ & 625,1667 & $*$ & 0,00005 & $\mathrm{~ns}$ \\
Secagem & 1 & 104499,1248 & $* *$ & 1120,6667 & $* *$ & 1666,6667 & $* *$ & 0,0062 & $* *$ \\
\hline $\begin{array}{l}\text { Estádio x } \\
\text { secagem }\end{array}$ & 2 & 7769,4901 & $* *$ & 236,1667 & $\mathrm{~ns}$ & 93,1667 & $\mathrm{~ns}$ & 0,0001 & $\mathrm{~ns}$ \\
\hline Resíduo & 18 & 73,3573 & & 71,3333 & & 125,3333 & & 0,00001 \\
\hline CV & & 8,84 & & 10,87 & & 15,09 & & 24,55 \\
\hline
\end{tabular}

TABELA 2 - Valores de condutividade elétrica das sementes de soja, cultivar MG/BR46, em diferentes estádios de maturação, sem secagem e submetidas à secagem. UFLA, 2005.

\begin{tabular}{|c|c|c|c|}
\hline \multirow[t]{2}{*}{ Estádio } & \multirow{2}{*}{$\begin{array}{l}\text { Umidade } \\
(\%)\end{array}$} & \multicolumn{2}{|c|}{$\begin{array}{c}\text { Condutividade elétrica } \\
\mu \mathrm{mhos} . \mathrm{cm}^{-1} \cdot \mathrm{g}^{-1}\end{array}$} \\
\hline & & Sem secagem & Com secagem \\
\hline R6 & 57 & $33,63 \mathrm{aA}$ & $216,74 \mathrm{cB}$ \\
\hline $\mathrm{R} 6 / \mathrm{R} 7$ & 55 & $31,19 \mathrm{aA}$ & $181,46 \mathrm{bB}$ \\
\hline $\mathrm{R} 7$ & 50 & $27,94 \mathrm{aA}$ & $90,48 \mathrm{aB}$ \\
\hline
\end{tabular}

Médias seguidas da mesma letra minúscula não diferem entre si na coluna e de mesma letra maiúscula não diferem entre si na linha, pelo teste de de Scott-Knott a 5\% de probabilidade.

Ciênc. agrotec., Lavras, v. 31, n. 3, p. 773-780, maio/jun., 2007 
TABELA 3 - Porcentagem de germinação, de teste de frio e peso seco de plântulas, de sementes de soja , cultivar MG/ BR46, sem secagem e submetidas à secagem. UFLA, 2005.

\begin{tabular}{lccc}
\hline \multicolumn{1}{c}{ Secagem } & Germinação \% & Teste de frio \% & Peso seco \\
\hline Sem secagem & $85 \mathrm{a}$ & $83 \mathrm{a}$ & $0,0131 \mathrm{~b}$ \\
Com secagem & $71 \mathrm{~b}$ & $66 \mathrm{~b}$ & $0,0179 \mathrm{a}$ \\
\hline
\end{tabular}

Médias seguidas da mesma letra não diferem entre si na coluna, pelo teste de Scott-Knott a 5\% de probabilidade.

Para os resultados do teste de frio, após a secagem as sementes também apresentaram um menor valor quando comparadas com as sementes não secadas (Tabela 3). Em relação aos estádios de maturação podese verificar valor acima de $84 \%$ para as sementes colhidas em R7, com $50 \%$ de umidade, enquanto que as colhidas em R6, com 57\% de umidade, o valor do teste de frio foi de $67 \%$ (Figura 1). Diversos autores comprovaram que embebição de sementes a baixas temperaturas pode causar danos às plântulas, resultando na redução da germinação. Neste trabalho, as sementes menos tolerantes sofreram mais com a baixa temperatura no teste de frio, do que as colhidas em estádio mais tolerante.

Analisando-se os resultados de peso seco de plântulas (Tabela 3), verifica-se que quando as sementes foram secadas, ocorreu um aumento significativo no vigor quando comparadas com as sementes não secadas artificialmente, resultado inverso aos encontrados nos outros testes, em que as sementes secadas apresentaram piores resultados de germinação, teste de frio e de condutividade elétrica. Vale ressaltar que o peso seco foi determinado nas plântulas originadas do teste de frio. Alguns autores comprovaram que embebição de sementes à baixa temperatura, assim como danos causados por altas temperaturas, pode causar danos no sistema radicular, resultando na redução da germinação, o que tem sido denominado "dano de embebição a frio" e as membranas têm sido consideradas como o local desses danos segundo Cal \& Obendorf (1972). Segundo Herter \& Burris (1989), danos de secagem e sensibilidade ao frio estão relacionados e, como a secagem a altas temperaturas danifica membranas, a tolerância ao frio será, também, reduzida. Portanto, é provável que a porcentagem de emergência das plântulas no teste de frio, tenha apresentado um baixo valor, devido principalmente aos danos de secagem nas raízes, os quais foram intensificados no teste de frio. Como o peso seco foi determinado apenas na parte aérea das plântulas, e estas são menos danificadas em danos de secagem, os valores foram maiores nas sementes secadas do que nas sem secagem.

$\mathrm{Na}$ Tabela 4, pode-se observar a comparação dos resultados da avaliação da qualidade fisiológica da testemunha (secada no campo) com os resultados de cada tratamento individualmente. No teste de condutividade elétrica, a testemunha apresentou resultado melhor do que todas as sementes secadas artificialmente, em qualquer estádio de colheita; e resultado pior do que todas as sementes não secadas. O pior resultado da testemunha em relação às sementes úmidas não indica, necessariamente, a sua pior qualidade fisiológica. É provável que as diferenças sejam devidas aos diferentes teores de água que as sementes apresentavam no início do teste de condutividade elétrica. À medida que as sementes perdem água, naturalmente ou através do processo de secagem artificial, ocorre desorganização das membranas celulares, e quando as sementes são colocadas em contato com substrato úmido, ocorre rápida e intensa liberação de eletrólitos, normalmente seguida por uma fase em que a quantidade de solutos vai decrescendo à medida que os tecidos são reidratados, até atingirem um estado de equilíbrio (SIMON \& RAJA-HARUM, 1972). Essa perda de solutos ocorre, principalmente pelas sementes com sistemas de membranas mais danificados. Sabe-se que, durante as primeiras horas de embebição, todas as sementes lixiviam solutos, mesmo aquelas cujos sistemas de membranas apresentam-se intactos, mas a quantidade de solutos decresce com o tempo de embebição. Já os menores valores de condutividade elétrica apresentados pela testemunha, em relação às sementes secadas artificialmente, indicam certamente, a qualidade superior da testemunha. Segundo Rosa et al. (2000b), a secagem natural parece ser menos danosa que a secagem artificial. 


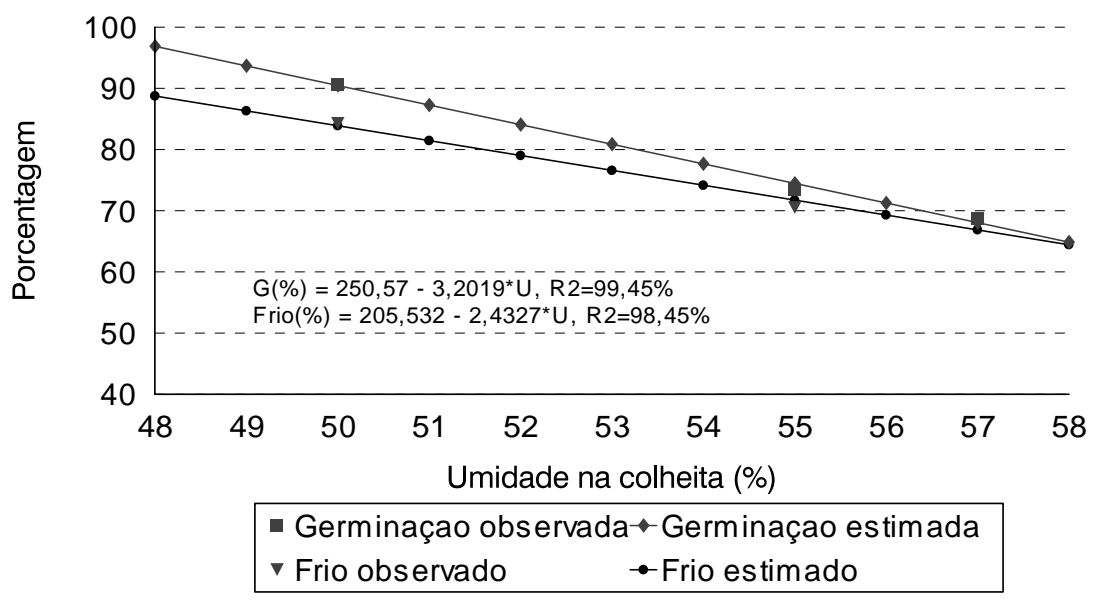

FIGURA 1 - Regressão dos valores de germinação e de teste de frio das sementes de soja, cultivar MG/BR46, em função da umidade na colheita. UFLA, 2005.

Pelo teste de germinação, verificou-se que a testemunha, secada no campo foi estatisticamente igual às sementes sem secagem colhidas em R6/R7 (55\% de umidade) e às colhidas em R7 (50\% de umidade); e estatisticamente superior do que as colhidas mais precocemente (R6 - 57\% de umidade) e às colhidas em R6 e R6/R7 e submetidas à secagem (Tabela 4). Pelo resultado de germinação verificou-se que as sementes colhidas em R7 toleraram melhor a secagem, uma vez que se igualaram à testemunha secada no campo. Este fato também foi confirmado pelos resultados do teste de frio, em que podese constatar que estas sementes (R7 secadas artificialmente) também foram iguais estatisticamente à testemunha.

As sementes secadas no campo (testemunha), em relação aos resultados do teste de frio, diferenciaram apenas das sementes colhidas no estádio R6 (57\% de umidade) e secadas em secador.

Em relação ao peso seco de plântulas, as sementes secadas no campo não apresentaram diferença significativa com os demais tratamentos e foram observados valores mais próximos aos das sementes colhidas em R7 e secadas em secador.

Os perfis eletroforéticos de proteínas lea são apresentados na Figura 2. Analisando os padrões de bandas apresentadas, ficam evidentes as alterações nas proteínas. Observa-se um aumento na intensidade das bandas 1 e 3 com o avanço da perda de água, desde as sementes úmidas até aquelas secadas até $13 \%$ de teor de água, em todos os estádios de colheita. As sementes secadas no campo e colhidas com $13 \%$ de teor de água apresentaram maior intensidade de bandas, ou um maior conteúdo de proteínas resistentes ao calor, indicando que a secagem induziu a síntese em sementes colhidas com altos teores de água, sugerindo o que ocorreria no campo com a secagem natural.

Observou-se também o aparecimento da banda 2 nas sementes colhidas no estádio R7 com 50\% de umidade quando secadas por 2 horas a $35^{\circ} \mathrm{C}$ ( $20 \%$ de umidade), o que não foi observado nos demais estádios, mas apenas nas sementes secadas até $14 \%$ de umidade. Esta banda também foi visível nas sementes secadas no campo e este padrão confirma os resultados dos testes fisiológicos, quando foi possível verificar a melhor qualidade das sementes com o avanço da maturação. Essas proteínas são acumuladas durante a secagem na maturação e, a sua estabilidade e hidrofilicidade e sua abundância em organismos tolerantes à dessecação, sugerem um papel associado à tolerância à secagem (BLACKMAN et al., 1991).

Ciênc. agrotec., Lavras, v. 31, n. 3, p. 773-780, maio/jun., 2007 
TABELA 4 - Resultados da avaliação de qualidade fisiológica das sementes de soja, cultivar BR46, em diferentes estádios de maturação, sem secagem e submetidas à secagem, comparadas com a testemunha secada no campo. UFLA, 2005.

\begin{tabular}{|c|c|c|c|c|c|c|}
\hline \multicolumn{2}{|c|}{ Tratamentos } & \multirow{2}{*}{$\begin{array}{c}\begin{array}{c}\text { Umidade } \\
(\%)\end{array} \\
57\end{array}$} & \multirow{2}{*}{ 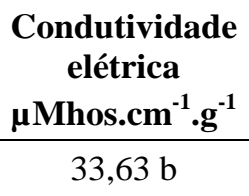 } & \multirow{2}{*}{$\begin{array}{c}\begin{array}{c}\text { Germinação } \\
(\%)\end{array} \\
74 \text { b }\end{array}$} & \multirow{2}{*}{$\begin{array}{c}\text { Teste de frio } \\
(\%) \\
80 \mathrm{a}\end{array}$} & \multirow{2}{*}{$\begin{array}{c}\begin{array}{c}\text { Peso seco de } \\
\text { plântulas } \\
(\mathbf{g})\end{array} \\
0,01258 \mathrm{a}\end{array}$} \\
\hline \multirow{3}{*}{$\begin{array}{l}\text { Sem } \\
\text { secagem }\end{array}$} & R6 & & & & & \\
\hline & R6/R7 & 55 & $31,19 \mathrm{~b}$ & $87 \mathrm{a}$ & $77 \mathrm{a}$ & 0,01391 a \\
\hline & R7 & 50 & $27,94 \mathrm{~b}$ & $94 \mathrm{a}$ & $91 \mathrm{a}$ & $0,01284 \mathrm{a}$ \\
\hline \multirow{3}{*}{$\begin{array}{l}\text { Com } \\
\text { secagem }\end{array}$} & R6 & 13 & $216,74 \mathrm{~b}$ & $64 \mathrm{~b}$ & $56 \mathrm{~b}$ & $0,01406 \mathrm{a}$ \\
\hline & R6/R7 & 13 & $181,46 \mathrm{~b}$ & $61 \mathrm{~b}$ & $65 \mathrm{a}$ & 0,01635 a \\
\hline & $\mathrm{R} 7$ & 13 & $90,48 \mathrm{~b}$ & $88 \mathrm{a}$ & $78 \mathrm{a}$ & $0,02336 \mathrm{a}$ \\
\hline Testemunha & $\mathrm{R} 8$ & 14 & $63,16 \mathrm{a}$ & $89 a$ & $85 \mathrm{a}$ & $0,01931 \mathrm{a}$ \\
\hline
\end{tabular}

Tratamento com a mesma letra minúscula da testemunha, na coluna, não difere da mesma, para o valor de significância de 5\%, pelo teste Dunneett.

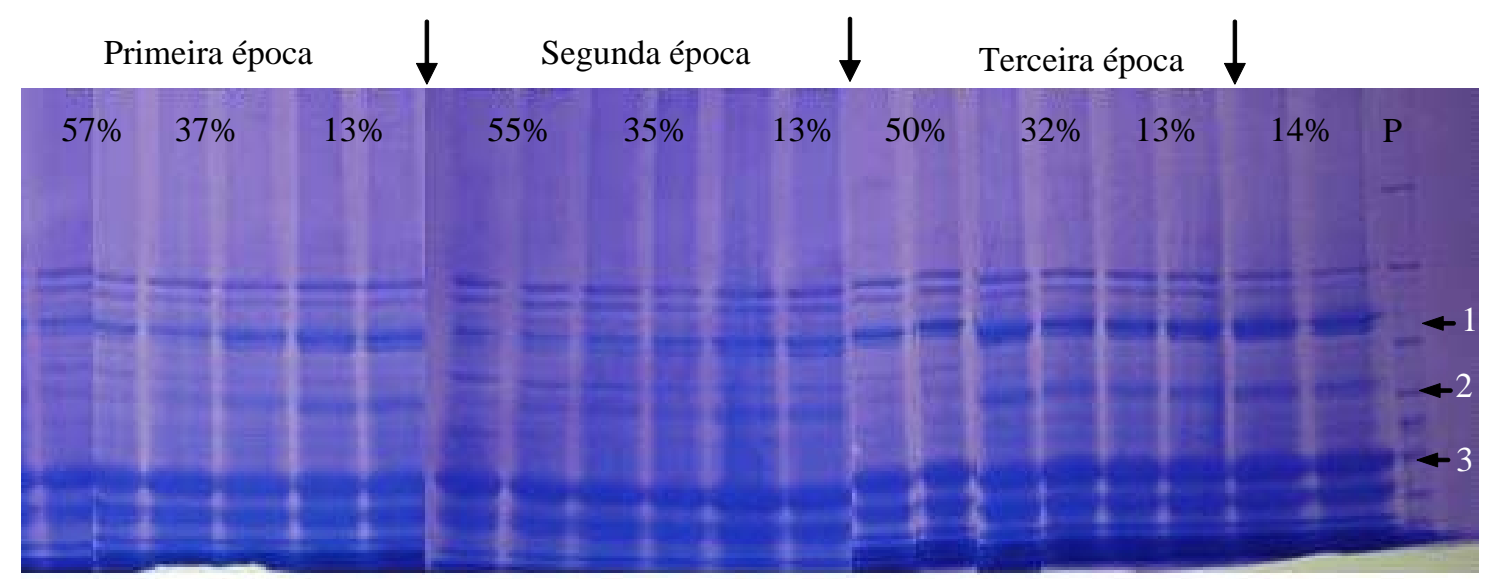

FIGURA 2 - Eletroforese de lea proteínas em sementes de soja, colhidas em diferentes estádios de maturação e submetidas à secagem artificial. UFLA, 2005.

\section{CONCLUSÕES}

A germinabilidade e a tolerância à dessecação de sementes de soja aumentam com a perda natural de água no campo.

Sementes colhidas no estádio R7 apresentam maior qualidade fisiológica, padrão diferenciado de proteínas lea e maior tolerância à dessecação do que nos estádios R6 e R6/R7.

Secagem de sementes colhidas próximo à maturidade induz a síntese de lea proteínas.

Sementes colhidas no estádio R7 apresentam qualidade fisiológica e padrão de proteína lea similares aos de sementes secadas no campo até $14 \%$ de teor de água.

\section{REFERÊNCIAS BIBLIOGRÁFICAS}

ALFENAS, A. C. Eletroforese de izoenzimas e proteínas afins: fundamentos e aplicações em plantas e microorganismos. Viçosa: UFV, 1998. 574 p.

ANDREWS, C. H. Some aspects of pod and seed development in Lee soybeans. 1966. 75 f. Tese (Ph.D.) Mississipi State University, State College, 1966.

BEWLEY, J. D.; BLACK, M.Seeds: physiology of development and germination. New York: Plenum, 1985. 367 p. 
BEWLEY, J. D.; BLACK, M. Seeds: physiology of development and germination. New York: Plenum, 1994. 445 p.

BLACKMAN, S. A.; WETTLAUFER, S. H.; OBENDORF, R. L.; LEOPOLD, A. C. Maturation proteins associated with desiccation tolerance in soybean seeds. Plant Physiology, Rockville, v. 96, p. 868-874, 1991.

BRASIL. Ministério da Agricultura. Regras para análise de semente. Brasília, DF: Secretaria Nacional de Defesa Agropecuária, 1992. 365 p.

CAL, J. P.; OBENDORF, R. L. Imbibitional chilling injury in Zea Mays L. altered by initial kernel moisture and maternal parent. Crop Science, Madison, v. 12, p. 369373, 1972.

NETER, J.; WASSERMAN, W.; KWTNER, M. H. Applied linear statistical models egression: analysis of variance and experimental designs. Burr Ridge: Irwin, 1990. 1181 p.

ELLIS, R. H.; HONG, T. D. Inducion of desiccation tolerance in seeds. In: WORKSHOP ON IMPROVED METHODS FOR HANDLING AND STORAGE OF INTERMEDIATE/ RECALCIFRANT TROPICAL FOREST TREE SEEDS, 1995, Humlebaek, Denmark. Proceedings... Humlebaek: [s.n.], 1996. p. 127-135.

ELLIS, R. H.; HONG, T. D.; ROBERTS, E. H. The development of desiccation-tolerance and maximum seed quality during seed maturation in six grain legumes. Annals of Botany, London, v. 59, p. 23-29, 1987.

FERH, W. R.; CAVINESS, C. E. Stages of soybean development. Ames: Iowa State University, 1979. 12 p.

FERREIRA, D. F. Sistema de análise estatística - SISVAR. Lavras: UFLA, 2000.

FISCHER, W.; BERGFELD, R.; PLACHY, C.; SCHAFER, R.; SCHOPTE, P. Accumulation storage materials, precocious germination and development of desiccation tolerance of seed maturation in mustard (Sinapis Alba L.). Botany, [S.1.], v. 101, p. 344-354, 1988.

HERTER, U.; BURRIS, J. S. Changes in moisture, temperature, and quality during high-temperature drying. Canadian Journal of Plant Science, Ottawa, v. 69, n. 3, p. 749-761, 1989.
KERMODE, A. R. Appoaches to elucidate the basis of desiccation-tolerance in seed. Seed Science Research, Wallingford, v. 7, p. 75-95, 1997.

KERMODE, A. R.; BEWLEY, J. D. The role of maturation drying in the transition from seed development to germination: acquisition of desiccation tolerance and germinability during development of Ricinus communis L. seeds. Exp. Botany, [S.1.], v. 36, p. 1906-1915, 1985.

KERMODE, A. R.; BEWLEY, J. D. Developing seeds of Ricinus communis L. when detached and maintained in atmosphere of high relative humidity, switch to a germinative mode without the requirement for complete desiccation. Plant Physiology, Rockville, v. 90, n. 3, p. 702707, 1989.

KRYZANOWSKI, F. C.; FRANÇA NETO, J. B.; HENNING, A. A. O teste de vigor. Informativo Abrates, Brasília, v. 2, n. 1, p. 15-50, 1991.

LONG, S. R.; DALE, R. M. R.; SUSSEV, I. M. Maturation and germination of Phaseolus vulgaris embryone axes in culture. Planta, Berlin, v. 153, p. 405-415, 1981.

POWELL, A. A. Cell membranes and seed leachate conductivity in relation to the quality of seed for sowing. Journal of Seed Tecnology, Springfield, v. 10, n. 2, p. 81-100, 1986.

RITCHIE, S. W.; HANWAY, J. J.; THOMPSON, C. E.; BENSON, G. O. How a soybean plant develops. Ames: Iowa State University of Science and Technology, 1994. 20 p.

ROSA, S. D. V. F.; PINHO, E. V. R. von; VIEIRA, M. G. G. C.; VEIGA, R. D. Indução de tolerância à alta temperatura de secagem em sementes de milho por meio de précondicionamento a baixa temperatura. Revista Brasileira de Milho e Sorgo, Sete Lagoas, v. 3, n. 2, p. 290-310, ago. 2000a.

ROSA, S. D. V. F.; PINHO, E. V. R. von; VIEIRA, M. G. G. C. Eficácia do teste de condutividade elétrica para uso em estudos de danos de secagem em sementes de milho. Revista Brasileira de Sementes, Campinas, v. 22, n. 1, p. 54-63, 2000 b.

SIMON, E. W.; RAJA-HARUN, R. M. Leakage during seed imbibition. Journal of the Experimental Botany, Oxford, v. 23, n. 77, p. 1076-1085, 1972.

SUN, W. O.; LEOPOLD, A. D. Acquisition of desiccation tolerance in soybeans. Physiology Plant, Minneapolis, v. 87, p. 403-409, 1993. 